\title{
A review of the benefits of electronic detonators
}

\author{
Uma revisão das vantagens dos \\ detonadores eletrônicos
}

\author{
Marilena Cardu \\ Department of Environment, \\ Land and Infrastructures (DIATI), \\ Politecnico di Torino, Italy. \\ IGAG C.N.R., Turin, Italy. \\ marilena.cardu@polito.it

\section{Alessandro Giraudi \\ Department of Environment, Land and Infrastructures (DIATI), Politecnico di Torino, Italy.} \\ alessandro.giraudi@piniassociati.com
}

\section{Pierpaolo Oreste}

Department of Environment, Land and Infrastructures (DIATI), Politecnico di Torino, Italy. IGAG C.N.R., Turin, Italy. pierpaolo.oreste@polito.it

\section{Resumo}

A perfuração computadorizada e a temporização eletrônica das detonações são dois avanços tecnológicos que têm tido um papel importante na atualização dos métodos de escavação com explosivos. Apesar disso, a temporização eletrônica dos detonadores ainda é uma solução técnica pouco frequente para problemas de detonação de precisão. Com base em uma extensa pesquisa bibliográfica, esse artigo revisa os resultados alcançados e as principais vantagens esperadas dos dispositivos eletrônicos de iniciação. Após descrever as características primárias desses detonadores, alguns elementos são considerados, a fim de que sejam melhor compreendidas as aplicações em diferentes condições, tanto em céu aberto quanto em subterrâneo, a extensão do número de tempos de retardo, a liberdade na escolha dos intervalos de tempo entre as detonações, a precisão da temporização, a redução das vibrações, o controle do overbreak e da fragmentação. Os resultados são comparados com aqueles obtidos por meio de dispositivos pirotécnicos de temporização e discutidos nas considerações finais.

Palavras-chave: Detonador eletrônico, detonador pirotécnico, perfuração e detonação, detonação de precisão, precisão na temporização.

\begin{abstract}
Computerized drilling and the electronic timing of detonations are two technological breakthroughs which have had an important role in updating drilling and blasting excavation methods, although the electronic timing of detonators is still a comparatively infrequent technical solution to precision blasting problems. On the basis of an extensive collection of published cases, this paper reviews the successes achieved and the main expected advantages from the electronic ignition devices. After describing the primary characteristics of these detonators, some elements will be considered, in order to better understand their applications in different conditions, both in open pit and underground sites: extension of the time delay number, freedom in the choice of time intervals between detonations, timing accuracy, reduction of vibrations, control of back-break and fragmentation. The results are compared to those obtained by pyrotechnical timing devices, and summarized in the concluding remarks.
\end{abstract}

Keywords: Electronic detonator, pyrotechnic detonator, Drill «Blast, precision blasting, timing accuracy. 


\section{Introduction}

Electronic devices (ED) were developed from an idea originated in the 1990s. Till now, EDs have been developed in Italy during the testing stage. They can fulfil the demand for increased accuracy, but their costly technology has hindered their expected growth.

In an ED, delay is achieved electronically; a computer chip is used to control delay timing. An integrated circuit chip and a capacitor internal to each detonator control the initiation time.

An electronic detonator has a number of advantages, e.g. higher precision, improved blasting result owing to a wide range of delays, reduction of airblast/ ground vibration, and safe use in extraneous electric environments, and the possibility of limiting the amount of detonators per shot. It has some disadvantages too, e.g. higher cost per detonator and the need for intensive training for users.

Conventional timing systems, to be compared to electronic timing, are listed in Table 1 and shown in the sketches (Figure 1). Electronic timing, in its turn, comprises electric detonators that include an ignition energy storage device and a programmable electronic timer, wired together with the programming, energy feeding and

\begin{tabular}{c|c|c}
\hline Systems & Components & Scheme \\
\hline $\begin{array}{c}\text { Electric with pyrotechnic delay } \\
\text { elements }\end{array}$ & $\begin{array}{c}\text { Blasting machine, wires, ignition pill, delay element, } \\
\text { primary or special NP (Non Primary) charge }\end{array}$ & $\mathrm{A}_{1}$ \\
\hline $\begin{array}{c}\text { Electric with separate circuits } \\
\text { powered in sequence }\end{array}$ & $\begin{array}{c}\text { Blasting machine (including a timer), wires, } \\
\text { ignition pill, primary or special NP charge }\end{array}$ & $\mathrm{A}_{2}$ \\
\hline $\begin{array}{c}\text { Non-electric with shock tube and } \\
\text { pyrotechnic delay elements }\end{array}$ & $\begin{array}{c}\text { Any source of priming shock, shock tubes, } \\
\text { pyrotechnic delay elements, detonating primary } \\
\text { or special NP charge (for branching } \\
\text { and for main charge detonation). }\end{array}$ & $\mathrm{A}_{3}$ \\
\hline $\begin{array}{c}\text { Non-electric with detonating cord } \\
\text { and pyrotechnic delay elements }\end{array}$ & $\begin{array}{c}\text { Any kind of detonator, detonating cord, } \\
\text { pyrotechnic delay elements (relays). }\end{array}$ & $\mathrm{A}_{4}$ \\
\hline Safety fuse & $\begin{array}{c}\text { Fuse ignition devices, fuse, blasting caps } \\
\text { Mixed systems }\end{array}$ & $\mathrm{A}_{5}$ \\
\hline $\begin{array}{c}\text { Most common: } \mathrm{A}_{1}+\mathrm{A}_{2}, \mathrm{~A}_{1}+\mathrm{A}_{3}, \mathrm{~A}_{1}+\mathrm{A}_{4}, \mathrm{~A}_{5}+\mathrm{A}_{3}, \mathrm{~A}_{5}+\mathrm{A}_{4}, \\
\text { but more complex system are possible }\end{array}$ & \\
\hline
\end{tabular}
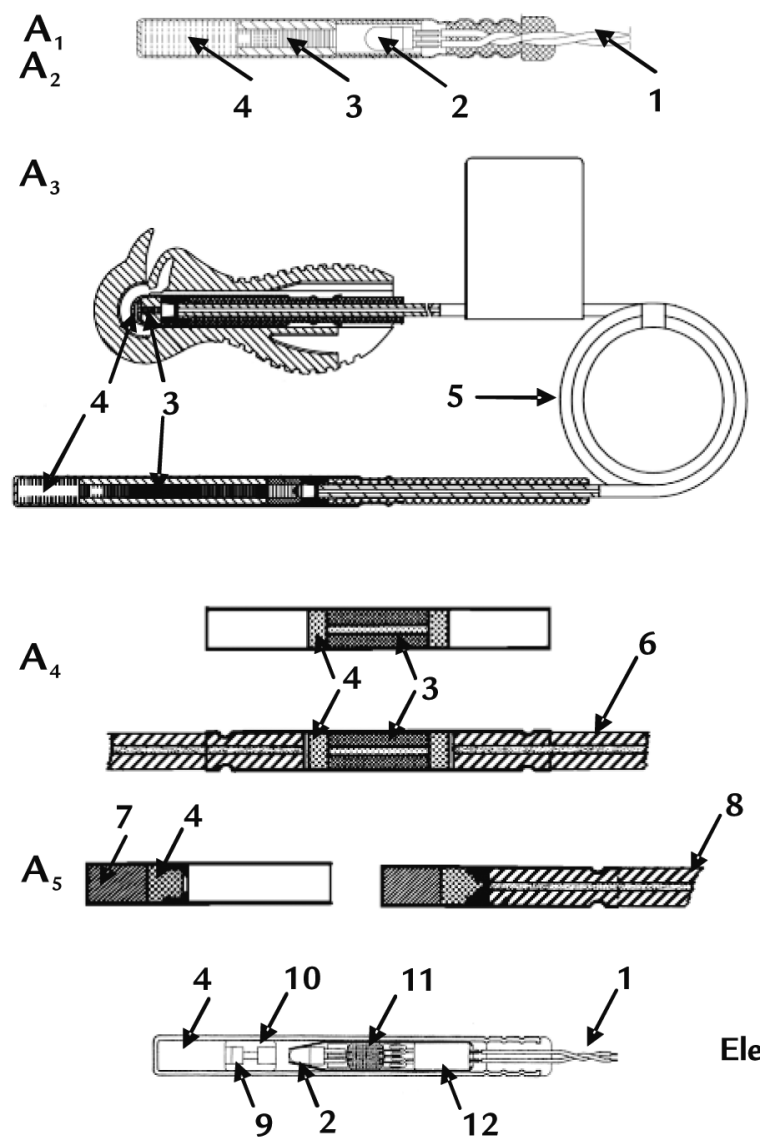

Electronic detonator
1. wires

2. ignition pill

3. delay element

4. primary or special NP charge

5. shock tube

6. detonating cord

7. secondary charge

8. safety fuse

9. initiating charge

10. initiating element tube

11. microchip

12. capacitor activation system. This makes it possible to decide freely, and obtain accurately, whatever distribution of detonation times is desired by the blast designer. Moreover, mixed systems (electronic $+\mathrm{A}_{3}$, electronic $+\mathrm{A}_{4}$ ) are possible.

Since the electronic detonators (and other components of the system, including the trained operator) are more expensive than conventional systems, the intrinsic advantages arising from the electronic timing option deserve to be weighted against the higher cost.

In Table 2, some relevant features of electronic systems are compared to

Table 1

Commonly used timing systems.
Figure 1

Sketches of conventional timing systems compared to electronic detonators. 


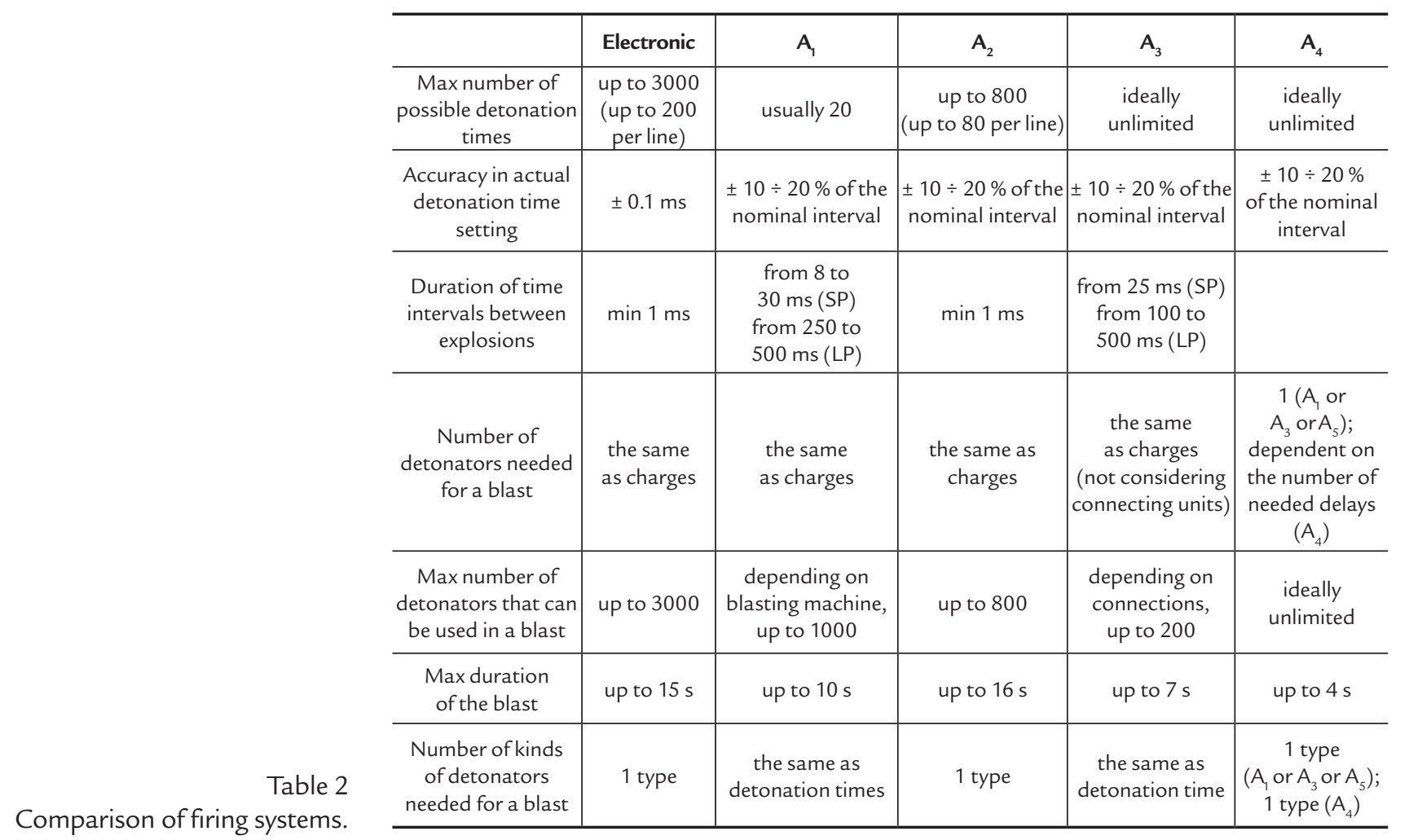

conventional systems. The safety fuse is disregarded, being used practically only in $\mathrm{A}_{5}+\mathrm{A}_{3}$ and $\mathrm{A}_{5}+\mathrm{A}_{4}$ mixed systems.

With regard to accuracy, there are some other considerations: flashover (owing mainly to inaccuracy in drilling and charging) is not affected by the timing systems; the detonation of a charge can last some $m s$ to some $m s$ depending on the explosive and the size of the cartridge; and inaccuracy of $m s$ in the detonation starting time definition implies an inaccuracy of some metres in knowing the space travelled by a detonation front in the explosive, by a shock front in a rock, or by the tip of a propagating crack. In practice, in addition to the congenital inaccuracy due to type of explosive and to its geometry, the inaccuracy (even only a few ms) due to the timing sequence must be taken into account.

Moreover, geometrical and geomechanical details of the mean are described forcibly in a statistical way, which adds some uncertainty: absolute accuracy of the results' prediction is not possible, even when laboratory tests on artificial materials are carried out.

More information is available in literature (Reisz et al., 2006). The accuracy of detonation times, however, rules out a great number of random effects, provided that the same care is taken in refining the explosion timing, drilling, charging and stemming.

In general, accurate and flexible tim- ing allows blasters to make small hole-tohole and row-to-row changes to account for drilling inaccuracies. Adjusting the blast design to actual conditions can improve safety and fragmentation, which can cut costs by optimizing the loading and hauling cycle, increasing crusher throughput, and reducing the amount of oversize handling and secondary breaking.

A great advantage of this type of detonator is its safety in the case of any stray currents, radar radiation or other electromagnetic interference, as well as its safety in the case of misuse. It cannot be fired simply by a battery or by other electric sources.

In addition, precise and variable delay timing organization enhances highwall stability and bench crest preservation, resulting in safer mine operations and in lower blast-induced ground vibrations. These improvements allow for more accurate placement of boreholes for subsequent blasts. Optimization of the blast design to take greater advantage of the electronic detonators' precision expands the blast pattern and reduces the explosive consumption, without negatively affecting production (Sharma, 2009).

Electronic detonators are generally programmable in $1 \mathrm{~ms}$ increments and have a delay accuracy (scattering) as low as $\pm 0.1 \mathrm{~ms}$.

Main blasting opportunities with electronic detonators are: frequency and peak particle velocity $(p p v)$ control; large open pit patterns (long delays); easiness of multiple decking initiation (minimal delay intervals); large stope blasting; fragmentation optimization; and delay period re-evaluation.

Incorrect timing of explosions (too long or too small an interval) affects the blast result according to different mechanisms:

- Seismic effect may be increased because of unwanted cooperation, or because the actual burden of a charge exceeds the ideal planned burden (as the rock to be broken by the previous explosion should be still firmly in place) or because of positive interference effects.

- Fly rock throw can be increased, either because rock removal by the previous explosion is in a too advanced stage, or because it is still insufficient; in the first case, burden is too small, in the second is too high and the ejection of stemming can take place, due to gun-effect.

- A lack of balance of the actual burdens between the charges of the blast gives rise to localized backbreak effects and to irregularities of the residual face and irregular fragmentation, even when the ideally expected burdens are measured accurately.

- In multi-row blasting, when the breaking line of a row is the free (or "almost free") face of the next row, any irregularity causes further irregularity in the fragmentation. 
The present work is the result of a detailed analysis of literature: some works refer to underground stopes, while others examine open pit mines and quarries. In order to evaluate the benefits from the use of EDs, the data considered (seismic

$$
\text { value } \%=\left(\frac{\text { data } E D}{\text { data } P D}-1\right) \cdot 100
$$

effects, fragmentation, and overbreak) are defined in the following, in percentage terms, according to the ratio (1):

\section{Opencast works}

The study by Sharma (2009) examines the structural response to blastinduced ground vibration. He underlines the importance, from an environmental point of view, of minimizing vibrations induced in urban dwellings by blasting. The maximum response of a building to blast-induced ground vibration occurs whenever the frequency of the ground vibration matches the natural resonant frequency of the structure: if there is little or no energy at the resonant frequency of the structure, the structural response to the vibration will be negligible.

By choosing delay times $(\Delta t)$ that create "destructive interference" at frequencies that are favoured by local geology, the vibration that excites structural elements could be reduced. In this method, accurate delay times are crucial for effective vibration control. Electronic detonators have less than $1 \mathrm{~ms}$ scatter. In this light, researchers have started to find both limitations and different potential in this new technique of controlling blast vibration.

The computer analysis determines the application of delay timing between holes, rows and decks which would produce the most favourable blast-induced vibrations for buildings and urban dwellings.

In Table 3 and Figure 2, data pertaining to ED and to pyrotechnic detona- tors (PD) are shown.

A reduction of the $p p v$ is noticeable when ED are used: this trend is shown in Figure 2, where scaled distances are plotted against peak particle velocities; data refer to 18 blasts that were fired during testing on site, 9 of them with PD and the rest with ED.

The study by Bartley et al. (1998) refers to the employment of a $60 \mathrm{~kg} / \mathrm{hole}$ charge per delay (cpd); the events were monitored at a distance varying from 400 $\mathrm{m}$ to $822 \mathrm{~m}$. Deacon et al. (1997) refer to another case, in which the cpd were in the $20-46 \mathrm{~kg} /$ hole range using $\mathrm{PD}$, and in the $16-20 \mathrm{~kg} /$ hole range using ED; the events were monitored at a distance of 140 to $180 \mathrm{~m}$ (using PD), and from 130 to 160 $\mathrm{m}$ (using ED).

During mining operations in a South African quarry (quartzite and sandstone) McFerren et al. (2004) adopted ED and PD (shock tube). The $c p d$ was $230 \mathrm{~kg}$ and the powder factor was $0.42 \mathrm{~kg} / \mathrm{m}^{3}$. The $p p v$ monitored by Chavez et al. (2003) are the results of the blast with the comparison of $\mathrm{ED}$ vs. PD, with interhole delays of $12 \mathrm{~ms}$ in a French limestone quarry. In the same paper, the reductions of $p p v$ generated by ED in another quarry are reported; 40 to $55 \%$ with respect to the $p p v$ obtained by PD.

\begin{tabular}{|c|c|c|c|c|c|c|c|}
\hline \multirow{2}{*}{ Authors: } & & \multicolumn{3}{|c|}{ ppv Min } & \multicolumn{3}{|c|}{ ppv Max } \\
\hline & & ED & PD & $\%$ & ED & PD & $\%$ \\
\hline $\begin{array}{c}\text { Deacon C., } \\
\text { Duniam P., } \\
\text { Jones M., } 1997\end{array}$ & & $8.85 \mathrm{~mm} / \mathrm{s}$ & $12.18 \mathrm{~mm} / \mathrm{s}$ & -27 & $13.54 \mathrm{~mm} / \mathrm{s}$ & $25.8 \mathrm{~mm} / \mathrm{s}$ & -47 \\
\hline \multirow{3}{*}{$\begin{array}{c}\text { Bartley D. A., } \\
\text { Trousselle R., } \\
1998\end{array}$} & Rad. & $0.25 \mathrm{~mm} / \mathrm{s}$ & $0.51 \mathrm{~mm} / \mathrm{s}$ & -51 & $5.21 \mathrm{~mm} / \mathrm{s}$ & $5.72 \mathrm{~mm} / \mathrm{s}$ & -9 \\
\hline & Vert. & $0.25 \mathrm{~mm} / \mathrm{s}$ & $0.38 \mathrm{~mm} / \mathrm{s}$ & -34 & $4.06 \mathrm{~mm} / \mathrm{s}$ & $3.94 \mathrm{~mm} / \mathrm{s}$ & 3 \\
\hline & Tran. & $0.64 \mathrm{~mm} / \mathrm{s}$ & $0.76 \mathrm{~mm} / \mathrm{s}$ & -16 & $7.49 \mathrm{~mm} / \mathrm{s}$ & $10.7 \mathrm{~mm} / \mathrm{s}$ & -30 \\
\hline \multirow{3}{*}{$\begin{array}{l}\text { Bartley D. A., } \\
\text { Winfield B., } \\
\text { McClure R., } \\
\text { Trousselle R. } \\
2000\end{array}$} & Rad. & $4.57 \mathrm{~mm} / \mathrm{s}$ & $3.3 \mathrm{~mm} / \mathrm{s}$ & 38 & $8.89 \mathrm{~mm} / \mathrm{s}$ & $5.84 \mathrm{~mm} / \mathrm{s}$ & 52 \\
\hline & Vert. & $2.54 \mathrm{~mm} / \mathrm{s}$ & $3.3 \mathrm{~mm} / \mathrm{s}$ & -23 & $6.1 \mathrm{~mm} / \mathrm{s}$ & $4.57 \mathrm{~mm} / \mathrm{s}$ & 33 \\
\hline & Tran. & $2.79 \mathrm{~mm} / \mathrm{s}$ & $5.08 \mathrm{~mm} / \mathrm{s}$ & -45 & $14.2 \mathrm{~mm} / \mathrm{s}$ & $7.11 \mathrm{~mm} / \mathrm{s}$ & 100 \\
\hline $\begin{array}{c}\text { IIR., Chantry R., } \\
2003\end{array}$ & & $3.0 \mathrm{~mm} / \mathrm{s}$ & $3.8 \mathrm{~mm} / \mathrm{s}$ & -21 & $5.0 \mathrm{~mm} / \mathrm{s}$ & $9.8 \mathrm{~mm} / \mathrm{s}$ & -49 \\
\hline $\begin{array}{c}\text { McFerren W., } \\
\text { Moodley P., } \\
2004\end{array}$ & & $0.13 \mathrm{~mm} / \mathrm{s}$ & $0.8 \mathrm{~mm} / \mathrm{s}$ & -84 & $24.3 \mathrm{~mm} / \mathrm{s}$ & $152.0 \mathrm{~mm} / \mathrm{s}$ & -84 \\
\hline
\end{tabular}

Few authors evaluate the frequency increase when EDs are employed. In particular, by using the relation $\mathrm{F}=1000 /$ delay to get the dominant frequency, the expected value of the frequency can be calculated (Deacon, 1997; Chavez, 2003).

As shown in Table 4, by adopting ED instead of PD an increase of frequency values is observed.

Also, the airblast levels were recorded by Baka Abu (2002) and McFerren et al. (2004) during mining operations. The first author obtained these results: the airblast levels were reduced from 127 $\mathrm{dB}$ to $108 \mathrm{~dB}(-15 \%)$ using ED instead PD. McFerren et al. (2004), during blasts initiated with ED instead of PD, observed a reduction of $3 \%$.

Another comparison between ED and PD is the rock fragmentation degree obtained from the blast (Table 5).

Grobler (2003) refers to the results obtained in surface mining, particularly on the log-linear plot of muck pile; ED produced a reduction in the upper size and the fines. In contrast, the grain size distributions related to ED, evaluated by König et al. (1994) and Havermann et al. (1995), are systematically higher compared to PD.

The study by Bartley (2001) of the post-blast muck pile excavation indicated a $25 \%$ reduction in dig time using ED.

Table 3

Comparison between different $p p v$ values, using ED and PD firing systems separately. 
Figure 2

The ppv data from Deacon et al. (1997) and Bartley et al. (1998) have been processed to obtain a comparison between ED and PD.

Table 4

Comparison between different frequency values using ED and PD firing systems separately.

Table 5

Rock fragmentation as a result of a blast, considering ED and $\mathrm{PD}$, respectively.

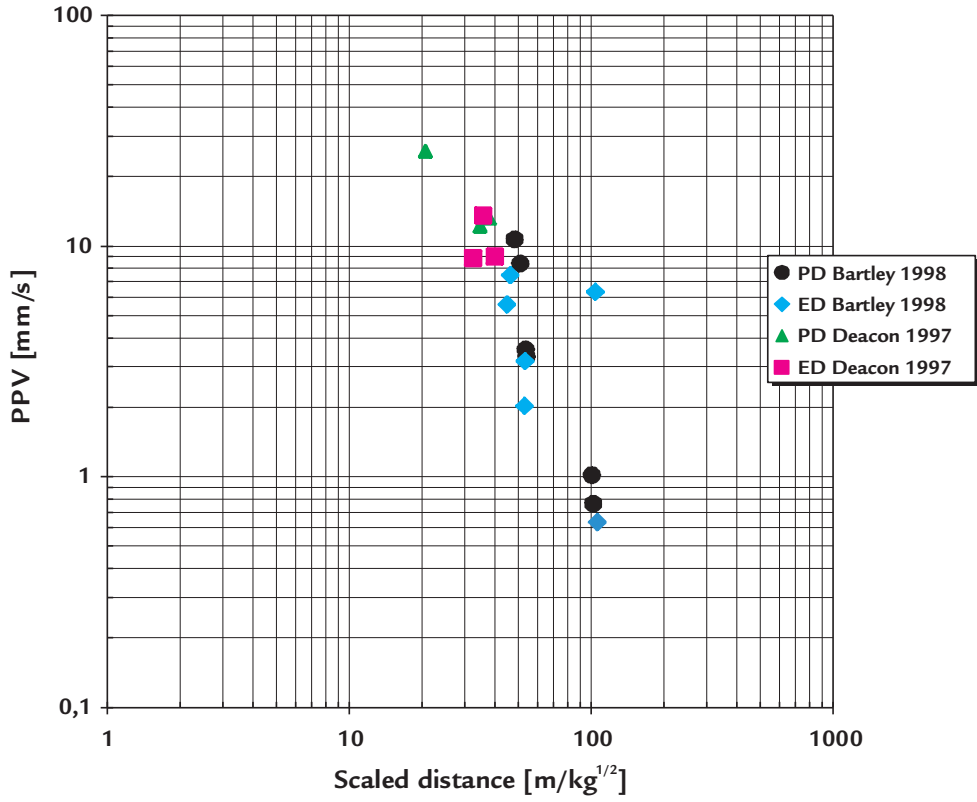

\begin{tabular}{c|c|c|c}
\hline Authors & ED & PD & $\%$ \\
\hline Bartley D. A., Trousselle R. 1998 & $26 \div 64 \mathrm{~Hz}$ & $20 \div 47 \mathrm{~Hz}$ & $30 \div 36 \%$ \\
\hline $\begin{array}{c}\text { Carter R. A., 2002 } \\
\text { Bartley D. A., Winfield B., McClure R., } \\
\text { Trousselle R., 2000 }\end{array}$ & $26 \div 39 \mathrm{~Hz}$ & $8 \div 20 \mathrm{~Hz}$ & $>95 \%$ \\
\hline McFerren W., Moodley P., 2004 & $30 \div 71 \mathrm{~Hz}$ & $26 \div 57 \mathrm{~Hz}$ & $15 \div 25 \%$ \\
\hline
\end{tabular}

\begin{tabular}{|c|c|c|c|c|c|c|c|c|c|}
\hline \multirow{2}{*}{ Authors } & \multicolumn{2}{|c|}{ Max Size } & & \multicolumn{2}{|c|}{ Mean Size } & & \multicolumn{2}{|c|}{ Min Size } & \multirow[b]{2}{*}{$\%$} \\
\hline & ED & PD & $\%$ & ED & PD & $\%$ & ED & PD & \\
\hline $\begin{array}{l}\text { Havermann T. } \\
\text { et al., } 1995\end{array}$ & $1500 \mathrm{~mm}$ & $1800 \mathrm{~mm}$ & $-17 \%$ & $255 \mathrm{~mm}$ & $410 \mathrm{~mm}$ & $-38 \%$ & $60 \mathrm{~mm}$ & $100 \mathrm{~mm}$ & $-40 \%$ \\
\hline $\begin{array}{l}\text { Deacon C., } \\
\text { Duniam P., } \\
\text { Jones M., } 1997\end{array}$ & $680 \mathrm{~mm}$ & $900 \mathrm{~mm}$ & $-24 \%$ & $125 \mathrm{~mm}$ & $200 \mathrm{~mm}$ & $-37 \%$ & $20 \mathrm{~mm}$ & $50 \mathrm{~mm}$ & $-60 \%$ \\
\hline $\begin{array}{c}\text { Bartley D. A., } \\
\text { Trousselle R., } \\
1998\end{array}$ & $1115 \mathrm{~mm}$ & $1485 \mathrm{~mm}$ & $-25 \%$ & $236 \mathrm{~mm}$ & $291 \mathrm{~mm}$ & $-19 \%$ & $13 \mathrm{~mm}$ & $21 \mathrm{~mm}$ & $-38 \%$ \\
\hline $\begin{array}{l}\text { König R., } \\
\text { Petzold j., } \\
1998\end{array}$ & $1100 \mathrm{~mm}$ & $1500 \mathrm{~mm}$ & $-27 \%$ & $250 \mathrm{~mm}$ & $400 \mathrm{~mm}$ & $-37 \%$ & $75 \mathrm{~mm}$ & $100 \mathrm{~mm}$ & $-25 \%$ \\
\hline \multirow{2}{*}{$\begin{array}{l}\text { Petzold J., } \\
\text { Hammelmann F. } \\
2000\end{array}$} & \multicolumn{3}{|c|}{$812.8 \mathrm{~mm}$ passing } & \multicolumn{3}{|c|}{$406.4 \mathrm{~mm}$ passing } & \multicolumn{3}{|c|}{$202.3 \mathrm{~mm}$ passing } \\
\hline & $78.30 \%$ & $63.20 \%$ & $19 \%$ & $34.90 \%$ & $24.10 \%$ & $45 \%$ & $9.40 \%$ & $4.80 \%$ & $96 \%$ \\
\hline \multirow{2}{*}{$\begin{array}{l}\text { Bartley D. A. } \\
\text { et al., } 2000\end{array}$} & \multirow{2}{*}{\multicolumn{3}{|c|}{ - }} & & & & \multicolumn{3}{|c|}{$203 \mathrm{~mm}$ passing } \\
\hline & & & & $214 \mathrm{~mm}$ & $320 \mathrm{~mm}$ & $-33 \%$ & $76.70 \%$ & $55.90 \%$ & $-37 \%$ \\
\hline \multirow{2}{*}{$\begin{array}{l}\text { Mckinstry } \\
\text { R., Floyd J., } \\
\text { Bartley D., } 2002\end{array}$} & \multicolumn{3}{|c|}{$90 \%$ passing } & \multicolumn{3}{|c|}{$50 \%$ passing } & \multicolumn{3}{|c|}{$10 \%$ passing } \\
\hline & $3.98 *$ & $7.07 *$ & $-44 \%$ & $2.87 *$ & $2.92 *$ & $-2 \%$ & $1.44 *$ & $0.99 *$ & $45 \%$ \\
\hline \multirow{2}{*}{$\begin{array}{c}\text { Grobler H. P., } \\
2003\end{array}$} & \multicolumn{3}{|c|}{$90 \%$ passing } & \multicolumn{3}{|c|}{$50 \%$ passing } & \multicolumn{3}{|c|}{$10 \%$ passing } \\
\hline & $500 \mathrm{~mm}$ & $750 \mathrm{~mm}$ & $-33 \%$ & $70 \mathrm{~mm}$ & $70 \mathrm{~mm}$ & $0 \%$ & $10 \mathrm{~mm}$ & $3 \mathrm{~mm}$ & $233 \%$ \\
\hline \multirow{2}{*}{$\begin{array}{l}\text { McFerren W., } \\
\text { Moodley P., } \\
2004\end{array}$} & \multicolumn{3}{|c|}{$53 \mathrm{~mm}$ sieve aperture } & \multicolumn{3}{|c|}{$13.2 \mathrm{~mm}$ sieve aperture } & \multicolumn{3}{|c|}{$2 \mathrm{~mm}$ sieve aperture } \\
\hline & $10 \%$ & $17 \%$ & $-41 \%$ & $50 \%$ & $75 \%$ & $-33 \%$ & $90 \%$ & $95 \%$ & $-5 \%$ \\
\hline
\end{tabular}

* (block size, diameter of the equivalent sphere). 
Moreover, the crushing operations show a reduction of electric power consumption $(\mathrm{kWh} / \mathrm{t})$ of about $6-10 \%$ if EDs are employed.

\section{Underground works}

In the last 15 years, some applications of the electronic detonators have been developed, to be employed underground, especially in tunnelling. In some cases, electronic devices can be used even in mixed systems, as shown in Figure 3.

The study by Svärd (1993) refers to the employment of a $3 \mathrm{~kg} /$ hole charge per delay $(c p d)$, while Thomasson (2000) describes an event in which a $400 \mathrm{~g} /$ hole $c p d$ was adopted.

Cho (1997) refers to another case, in which the $c p d$ were in the 125-500 g/hole range in case of PD, and in the 125-375 g/hole range in case of sequential blasting. The events were monitored at a distance of 20 to
When EDs are employed, thanks to the improvement of the fragmentation, the block size distribution is upgraded (in comparison with $\mathrm{PD}$ ) as follows:

$33 \mathrm{~m}$ (in the case of PD), and from 21 to $42 \mathrm{~m}$ (in the case of sequential blasting). See Table 6 .

Some experimental blasts were carried out by Wetherelt (2007) for a comparative study of $p p v$ in a tunnel. In the first blast, PDs (non electric detonators) were employed, while in the second EDs (with the same delay times as in the previous case) were used. The results obtained by monitoring ground vibrations are shown in Figure 4; the $c p d$ employed for the tests was $1.60 \mathrm{~kg}$.

The comparison of an ED vs PD firing system in underground mining activities is not so relevant in terms of muck-pile fragmentation (see Table 7),

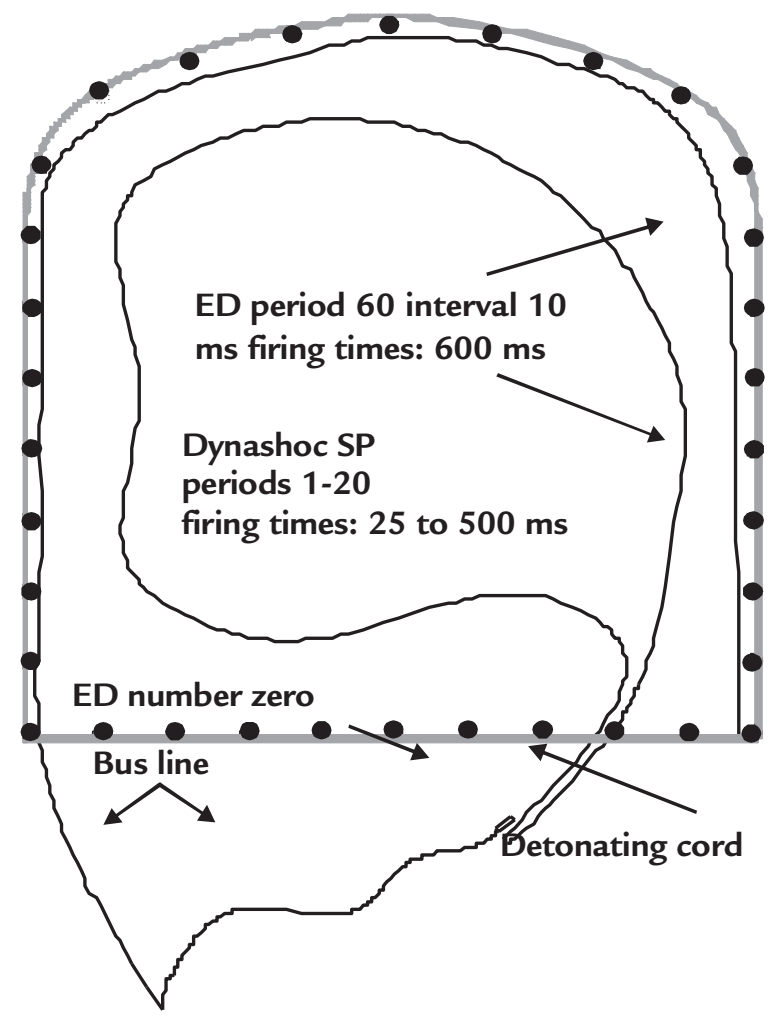

\begin{tabular}{c|c|c|c|c}
\hline Authors & & ED (mm/s) & PD (mm/s) & $\%$ \\
\hline \multirow{2}{*}{ Svärd J., 1993 } & 33 caps per round & 4 & 8 & $\mathbf{- 5 0}$ \\
\cline { 2 - 5 } & 44 caps per round & 9 & 16 & $-\mathbf{4 4}$ \\
\hline Thomasson C., 2000 & - & 7 & 12.1 & $\mathbf{- 4 2}$ \\
\hline Cho Y. D. et al., 1995 & & sequential blasting & - & $\mathbf{- 1 4} \div \mathbf{1 8}$ \\
\hline Wetherelt A., 2007 & & $2.25-65.02$ & $0.83-45.72$ & $\mathbf{4 0} \div \mathbf{2 9 2}$ \\
\hline
\end{tabular}

Figure 3

Priming pattern by employing the mixed system ED-PD (König R., 1994, Modified).

Table 6

Comparison between different ppv values by using ED and PD firing systems respectively. 
Figure 4

ppv data (taken from Wetherelt $\mathrm{A}$. 2007) have been processed to obtain a comparison between ED and PD.

Table 7

Rock fragmentation as a result of a blast, considering ED and $\mathrm{PD}$, respectively.

Table 8

Comparison between different profile accuracy values using ED and PD firing systems separately.

\section{Conclusions}

The results of this review show that the employment of EDs is advantageous in terms of vibration reduction, increased frequencies, airblast, improved fragmentation in the muck pile, diggability, crushing cost saving (less energy used during the primary and secondary fragmentation), and control of overbreak, which allows greater profile accuracy. Nevertheless, EDs' advantages are satisfied where an

\section{References}

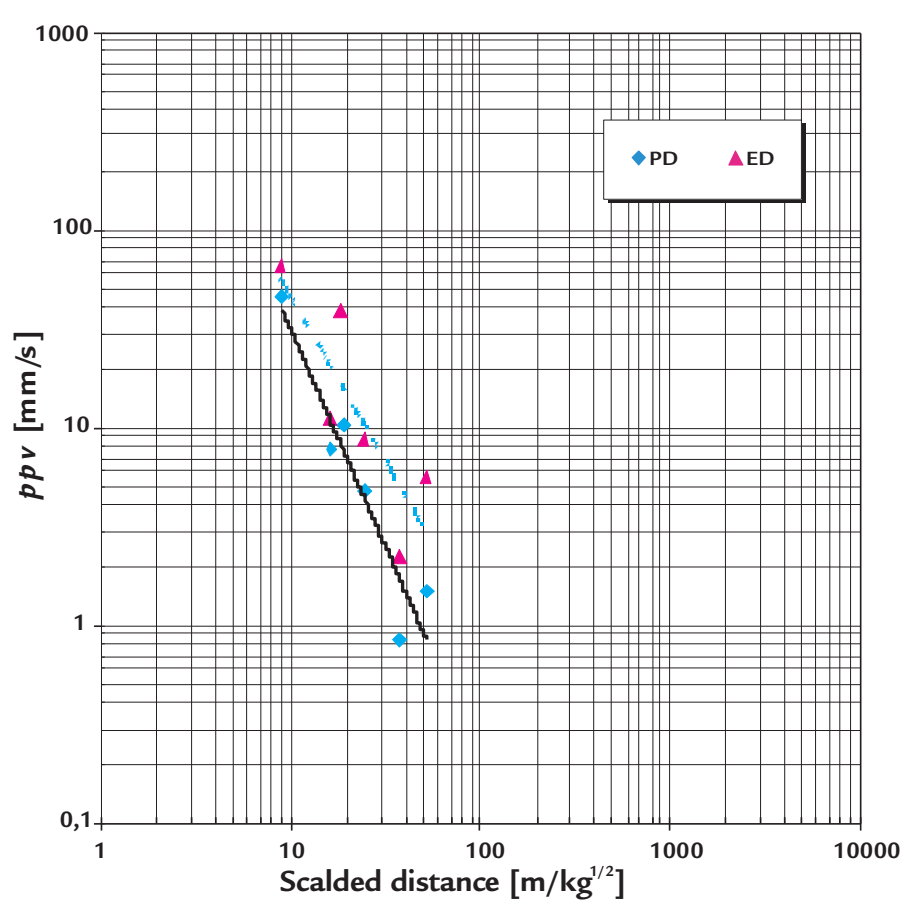

\begin{tabular}{c|c|c|c|c}
\hline Authors & Size & ED & PD & $\%$ \\
\hline \multirow{2}{*}{$\begin{array}{c}\text { Tose S. J., } \\
\text { Baltus C., } \\
2002\end{array}$} & $1000 \mathrm{~mm}$ & $98.8 \%$ & $98.2 \%$ & $\mathbf{1 \%}$ \\
\cline { 2 - 5 } & $300 \mathrm{~mm}$ & $72.8 \%$ & $77.4 \%$ & $-\mathbf{6 \%}$ \\
\cline { 2 - 5 } & $25 \mathrm{~mm}$ & $6.3 \%$ & $6.1 \%$ & $\mathbf{3 \%}$ \\
\hline
\end{tabular}

\begin{tabular}{c|c|c|c}
\hline \multirow{2}{*}{ Authors } & \multicolumn{2}{|c}{ Profil } & \\
\cline { 2 - 4 } & ED & PD & $\%$ \\
\hline Stratmann M. ,1996 & $10 \mathrm{~cm}$ & $25 \mathrm{~cm}$ & $-60 \%$ \\
\hline Fauske A., 1998 & - & - & $-60 \%$ \\
\hline Bleuzen Y. et al.,2005 & - & - & $-30 \%$ \\
\hline Yamamoto M. et al., 1995 & - & - & $-6 \%$ \\
\hline
\end{tabular}

accurate design of the blast and an adequate hole's drilling and charging are guaranteed.

As discussed, the electronic detonators provide more accurate timing than the conventional pyrotechnic detonators which rely on the combustion speed of a pyrotechnic composition. The timing accuracy capability of the electronic detonator allows for:
- More efficient application of explosive energy.

- Improved muck size uniformity.

- Increase in excavation productivity.

- Cost saving in excavation operations.

- Improved public acceptance of blasting.

- An additional benefit of electronic detonators. i.e. the improved control of blast-induced vibrations and airblast.

BARTLEY, D. A., TROUSSELLE, R. daveytronic digital detonator testing in a vibration sensitive environment. In: ANN. CONF. ON EXPLOSIVES AND BLASTING TECHNIQUE, 24. New Orleans, Louisiana, USA ISEE, 1998. p. 247-261.

BARTLEY, D. A., WINFIELD, B., MCCLURE, R., TROUSSELLE, R. Electronic detonator technology: Field application and safety approach. In: EFEE WORLD CONFERENCE ON EXPLOSIVES AND BLASTING, Munich, 2000. p. 149158. 
BARTLEY, D. A. Field applications and quantification of electronic detonator technology. ISEE, INT. CONF. ON EXPLOSIVES \& BLASTING TECHNIQUE, International Society of Explosives Engineers, 1-19. 2001.

BAKA ABU J. The Implementation of the Smartdet Universal System at Damang Gold Mine, Ghana. Marcus Evans Conference, New Paradigm Shift in Drilling and Blasting, Johannesburg, South Africa, 2002.

BLEUZEN, Y., MONATH, F., QUARESMA, M., JOÃO, M. Tunnel blasting in a sensitive environment using electronic detonators. The Journal of Explosives Engineering, p. 6-14, sep/oct, 2005.

CARTER, R. A. Plugging in to digital detonation: electronic sequencing and initiation systems can improve blasting performance and reduce neighbor complaints. Rock Products, p. 2830, may, 2002.

CHAVEZ, R., CHANTRY, R. Actual benefits from new technologies related to constant timing with electronic detonators and uniform energy control. In: EFEE WORLD CONFERENCE ON EXPLOSIVES AND BLASTING, 2. Prague, 2003, p. 303-311.

CHO Y. D., PARK, B. K., LEE, S. E., LIM, H. U. Application of full-face round by the sequential blasting machine in tunnel excavation. In: ISEE INT. CONF. ON EXPLOSIVES \& BLASTING TECHNIQUE, 21. International Society of Explosives Engineers, p. 108-120, 1995.

DEACON C., DUNIAM, P., JONES, M. Improved blast control through the use of programmable delay detonators. In: ISEE INT. CONF. ON EXPLOSIVES \& BLASTING TECHNIQUE, 23. International Society of Explosives Engineers, p. 55-68, 1997.

FAUSKE, A. La construccion de tuneles urbanos en Noruega. Rocas y Minerales, p. 62-74, july, 1998.

GROBLER, H. P. Using electronic detonators to improve all-round blasting performance. International Journal for Blasting and Fragmentation, v. 7, n. 1, p. 1-12, 2003.

HAVERMANN, T., VOGT, W., PLAUMANN, G., KÖNIG, R., THOMAS, K. Digitale Haufwerkanalyse von elektronisch gezündeten Sprengungen im Steinbruch Groß-Bieberau der Oden-wälder Hartstein-Industrie GmbH (OHI). Nobel Hefte, n.1, p. 1-9, 1995.

KÖNIG, R. Three modern firing methods are on choice. Nobel Hefte, n. 1, p. 1-12, 1994.

KÖNIG, R., PETZOLD, J. Diez años de experiencia con el sistema electrónico de iniciacion 'DYNATRONIC'. Rocas y Minerales, p. 60-66, nov., 1998.

MCFERREN, W., MOODLEY, P. Electronic detonator success: an african story". $30^{\text {th }}$ ISEE Int. Conf. on Explosives \& Blasting Technique. International Society of Explosives Engineers, p. 1-12, 2004.

MCKINSTRY, R., FLOYD, J., BARTLEY, D. Electronic detonator performance evaluation. The Journal of Explosives Engineering, p. 12-22, May/Jun, 2002.

PETZOLD J., HAMMELMANN, F. The second generation of electronic blasting systems. Int. Conf. on Explosives \& Blasting Technique, EFEE, p. 159-164, 2000.

REISZ W., MCCLURE, R., BATLEY, D. Why the $8 \mathrm{~ms}$ rule doesn't work. The Journal of Explosives Engineering, p. 14-22, (Jul/Aug), 2006.

SHARMA, P. D. Electronic detonators: Results in substantial techno-economic benefits for large mining operations. Mining Engineers' Journal, India (February), 2009.

STRATMANN, M. Moderne Bohr-und Sprengverfahren beim Vortrieb des Mitholztunnel. Nobel Hefte, 1/2, p. 31-39, 1996.

SVÄRD, J. Possibilities with accurate delay time. FRAGBLAST Rock Fragmentation by Blasting, 1, p. 71-78, 1993.

THOMASSON, C. Le tir aux détonateurs électroniques dans le tunnel de foix. Tunnels et Ouvrages Souterrains, p. 359-361, Nov/Dec, 2000.

TOSE, S. J., BALTUS, C. Comparison of the fragmentation results from the use of electronic detonators and shock tube initiating systems under similar mining conditions. Fragblast 7 Rock Fragmentation by Blasting, Beijing, p. 50-53, 2002.

WETHERELT, A. A comparative study of ppv analysis of tunnel rounds using both non electric and programmable electronic detonation. 33 ${ }^{\text {rd }}$ ISEE Int. Conf. on Explosives \& Blasting Technique, International Society of Explosives Engineers, p. 10, 2007.

YAMAMOTO, M., ICHIJO, T. TANAKA, Y. Smooth blasting with the electronic delay detonator. 21stSEE Int. Conf. on Explosives \& Blasting Technique, International Society of Explosives Engineers, p. 144-156, 1995.

Artigo recebido em 28 de junho de 2012. Aprovado em 28 de março de 2013. 